\title{
System Modeling of the Smart City in Context of Land Management E-Service
}

\author{
Volodymyr Nazarenko ${ }^{1}$ \\ ${ }^{1}$ Faculty of Land Management, National University of Life and Environmental Sciences of Ukraine, Kyiv, Ukraine \\ Correspondence: Volodymyr Nazarenko, Faculty of Land Management, National University of Life and \\ Environmental Sciences of Ukraine, Kyiv, 03041, Ukraine. Tel: 38-066-126-0476.
}

Received: March 1, $2021 \quad$ Accepted: March 15, $2021 \quad$ Online Published: March 29, 2021

\begin{abstract}
The smart city is a prominent field of research, which is at the intersection of broader fields of economics, social, and land sciences. Four core smart city research subfields were identified, specifically defined, and classified urbanization, city planning, and governance, land and resources management. In this paper author presented a classification of modern smart city research tools and introduced smart city, conceptual research model. Information system is critical in describing underlying principles of modern urbanization processes and modeling it is processed effectively. This scientific work aims to address the challenges any new researcher in this field encounters, such as lack of extensive overview and classification of available tools. The list of major economic aspects of the smart city system and the main services, that city provides, are introduced and explained within the scope of this article. The author presents a conceptual model of a smart city from both a general scientific viewpoint as well as in the context of information system modeling. Data is a key component of any system modeling process as well as it is an essential part of tool classification. This paper places emphasis on data classification by its application and its research subfield. A great deal of attention is paid towards system modeling of land management subsystems in the context of smart city digital service. This article can serve as a theoretical foundation for further research and practical implementation of future smart systems.
\end{abstract}

Keywords: smart city, urbanization, land management, spatial development, system modeling, urban economics

\section{Introduction}

In the next decades, cities will continue their role as major catalysts of rapid economic growth, land usage, and national development. Modern cities are leading centers of social, political, and economic activities. Modern research works, including United Nations urban development reports, point out that cities will be at forefront of economic development as well as present many new challenges. While western countries will maintain a high level of urbanization, centers of new urban growth will move to Asia and several other developing countries throughout the world. The economic focus will shift from resources and trade-based economy with a single center of business activity towards high technologies, industry 4.0, and multidirectional city growth and development plans. Urbanization itself is a continuous process, that is at forefront of economic transformation. There is no universal urbanization pattern in the world. Some cities are formed by merging smaller neighboring towns, some cities receive finance investments due to local placed businesses and rapidly grow in matters of years, in some country's cities are turning into a state of their own. Medium to large cities together with smaller suburbs towns and villages form urban clusters. Such clusters are play important role in both local and national economic development. Newly developed urban centers are the first to attract investments, workforce, and international businesses. Naturally one of key focus areas of financial investments and workforce are real estate and construction opportunities. Cities attract international investment institutions, financial organizations and private investors who are looking for the most profitable, stable, and secure locations to make long-term investments. Together with their benefit's large cities lead to many problems such as real estate market bubbles, mass unemployment due to technological changes, and pandemics which in turn can cause a shift of investment focus and lead to city decline. Urban centers can influence the whole region or even continent, lead to human resources migration, rapid land development, and construction boom. As the city central cluster develops it can impact and change neighboring suburban areas, which can turn into production and agricultural supplier of the city, turn bankrupt (ghost towns) or form new housing market for people who want to live outside of the large city. Another possibility for suburban areas is to become connected to the city and together share economic growth. Such effects can be seen on levels of households and business levels. In terms of city and regional governance, such urban center to suburban areas relations present 
a large portion of challenges. In general, they require the economic development plans to be changed and adapted with long-term vision. Modern technological advancement can help to manage city using digital information management systems.

Being a relatively new field of scientific study urbanization and city management presents many questions and issues to be addressed. It is a multidisciplinary field of research in the intersection of economic, land science, social science, informatics and mathematics, ecology, and sustainable development. One of the most prominent and novel areas of scientific work is establishing a connection between above mentioned scientific fields and applying for this work in the partial context of addressing real world issues. As a result of this, the author decided to focus his research on the smart city concept. Smart city field include land use and land management, financial market and national economics, human migration, extensive natural resources consumption, various ecological aftereffects. Other topics include population dynamics, land cover and green areas changes, traffic and architectural city planning, city infrastructure, and healthcare. The author believes that the system modeling approach will assist in solving these multidisciplinary research issues and help combine different fields of study. The purpose of conducted research work is to address the challenges any new researcher in this field encounters, such as lack of extensive system overview, information systematization, presentation, and classification of potential research tools.

This article provides the classification of modern smart city research tools and scientific research methods. It also deals with issues of research classification, what are the main subfield of smart city research. The author presents a list of scientific methods, tools, and systems that can be used in future research. Main smart city research tools were determined, they consist of such as computational, geospatial databases, information systems, and edocuments toolsets. Data is at the heart of any of the above-mentioned methodologies and toolsets. In this research work, we classified data by its field of application, scientific research subfield that it is part of. Among other fields, economics study is one of the major parts of modern urbanization research works. The most widely used fields of research in urban economics are city budget, cost of living in the city, employment data, and land prices. The paper highlights that city growth and development, land use and urbanization patterns, spatial planning and distribution are prominent subfields of economics research.

Effective and practical scientific work requires an understanding of underlying mechanics and knowledge not only of the field of study but of a set of tools that can be used for such work. The study of smart cities as a subfield of urbanization is a challenging task. Smart city system includes, among many other such areas as real estate, land use, governmental policies, and municipal governance regulations, geographical information, and social studies. Besides sustainable development, the concept of green cities and effective natural resources use planning have gained attention during the past decade and are at the focus of many modern researchers. Meanwhile, the current state of urbanization research has presented new challenges and research opportunities to work on. Smart city is mostly looked at as part of computer science field. This helps solve many of the current technical challenges and questions while neglecting the important fact that the city is at the heart of smart city system. To address issues and challenges of the city development research need to look at it from a multidisciplinary approach and take into account social land economic situation, as well as real estate and land market. Climate and sustainable development cannot be studied separately from the city as they are one of the key contributors to ecological changes. Smart city systems can and should include social aspects, waste generation and natural resources consumption, extensive land use, and rapid changes in construction patterns. It is evident that to proceed in their studies researchers in urbanization, smart city fields are required to establish a new set of methods and use all of the available tools. The advancement in computer science and the current state of computational capabilities allow for real-time system modeling, complex information storage, classification and presentation, geospatial data visualization, and 3D realtime simulation of real cities. In addition to this, the article presents the smart city scientific methodology research process. This process can serve as the foundation for future scientific efforts and work in smart city studies and adjacent fields.

\section{Data and Methodology}

\subsection{Data}

For the article, we used social, land use, and economic statistical data from several major cities, including the city of Kyiv and Ukraine State Statistics service. Important data that was used in the context of this research is city investments classification, city governance structure, local legislation, list of main city institutions, departments, labor market and employment, land and real estate markets, including its regulation. Available smart city and information systems architectures were studied to determine key components of such a system. Existing GIS and digital mapping solutions information architecture was considered while developing a smart system conceptual model and land management services. Economics is an essential part of urban studies and smart city system 
modeling. Economics research focus in this area is mainly centered around real estate, land property analysis, financial modeling, and price prediction. The author acknowledges that state of the art scientific approach to urbanization cannot be limited only to economics study, so it is no longer effective to have a smart city system to be centered around financial aspects and price modeling. Besides even the previous economics approach that mainly classified city economics as a subarea of microeconomics study. Instead, new findings and research tools provide a tremendous opportunity for a new shift in studies of city processes. It is evident that the urban process has an impact on the ecology situation, on local and national economic development, financial markets, and both national and international laws and regulations that govern the modern city. In this paper, we present tools and methods that can be used by different researchers coming from different areas of scientific study that revolve around land management, city governance information technologies, and social aspects of cities.

Figure 1 represents four main fields of conceptual smart city research - city planning, city services, legislation, and city technical infrastructure. Next to each field, we provided a list of main components, subfields of research. The conceptual smart city model is mostly based on the city of Kyiv, its structure, how the city council operates it, and publicly available city-data. Figure 2 focuses on the main economic aspects of the conceptual smart city system. City budget, specifically city spending, land, and natural resources management influence how such smart city system functions. Additionally, to financial spending city generate a great deal of waste and carbon emissions, power consumption. Any potential smart city system without a doubt must include ecological and sustainable development components.

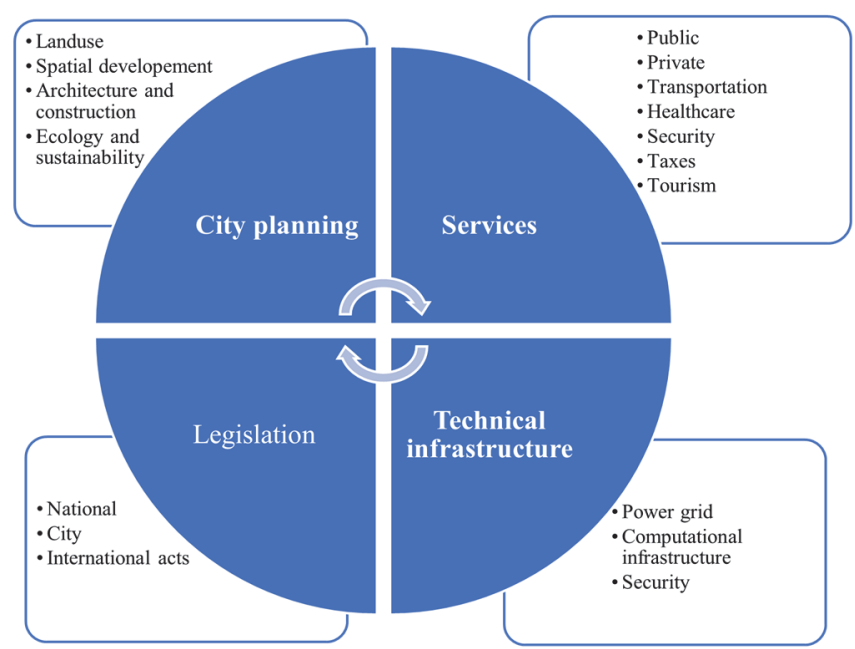

Figure 1. Smart city fields of research

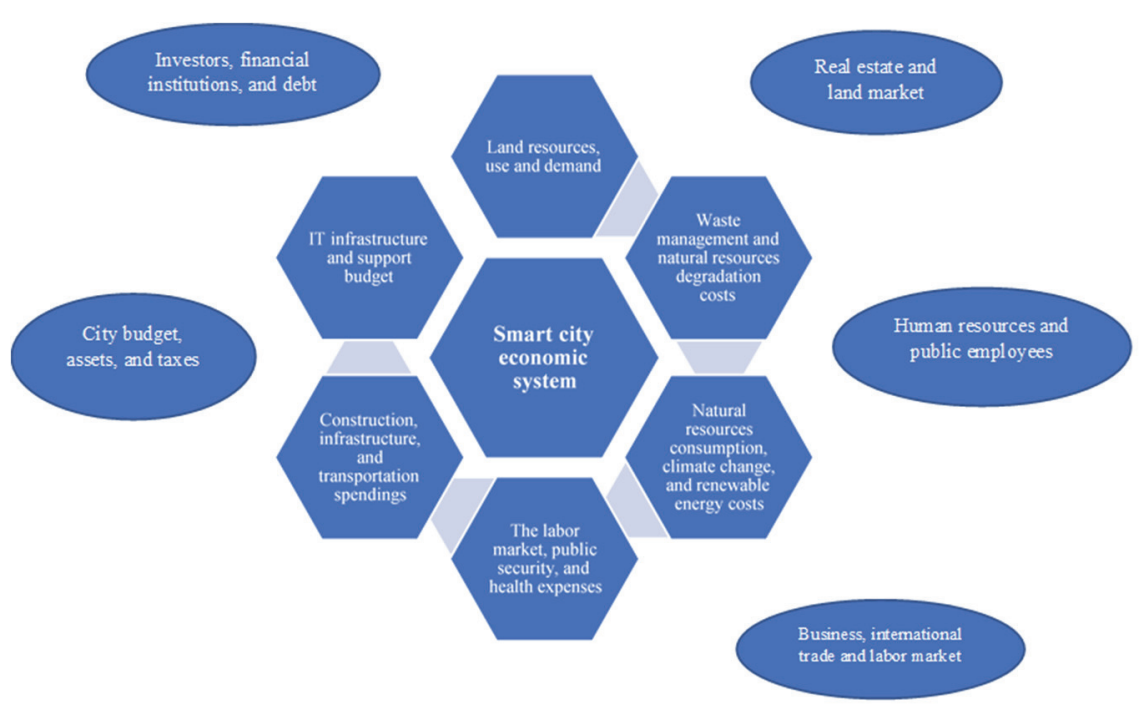

Figure 2. Economic aspects of smart city system 
Within the scope of smart city research, it is important to denote city governance structure, which may vary from country to country, list of major city-level institutions, and categorize the list of the city main services. Such classification is presented in Figure 3. The city consists of the main administration, the mayor and his office, elected city council (may vary depending on the country), national or federal institutions that can influence or directly control city council, city legislation, and public non-profit organization. In some cases, intentional organizations and international acts can directly include how cities operate. Police, healthcare, social services, and emergency response institutions are among essential city-level service providers. Architecture and land management are multifunctional services that are present in each city, they are at forefront of the conceptual smart city system. Each city needs people to live in it, as well as do work and use/build city infrastructure, which includes road cover, waste management, water supply, and power consumption. For any of the modern city an electronic document management system is an essential service. It is used for land and property management, in city finances, legislation, and planning services.
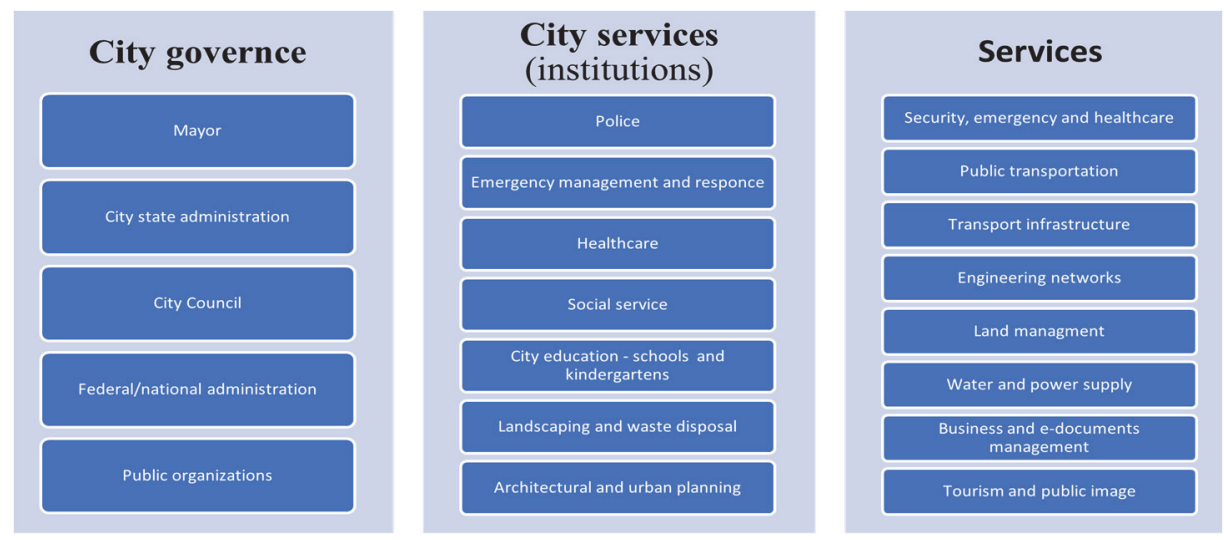

Figure 3. City governance and major city services classification

\subsection{Methodology}

Smart city as part of urbanization research is a new field of scientific study. It is a multidisciplinary and cross-field study, that includes economics, sociology, computer science, land management, and ecology at its core. At the same time, a large portion of scientific research papers is narrowly focused on certain subfields, such as GIS, spatial development, city management, technological infrastructure, solving specific computer technologies challenges, or real estate market analysis. The author notes the lack of comprehensive quality information that provides deep analysis and presentation of urbanization as a standalone scientific area. The process of smart city system modeling cannot be explored and studied without first establishing a set of tools and scientific methods that are related to this field. The author acknowledges scientific discoveries and considerable progress in the field of computer sciences. Computer science can serve as a strong scientific tools' foundation for modern urban studies. Without a doubt tools such as computer vision that enable us to effectively analyze and classify spatial data or advancement in the area of machine learning, that allows for robust real estate prediction models or real city models built using 3D modeling platforms, provide a strong argument for their use by urban researchers. Table 1 provides an overview of twelve smart city research subfields. They are grouped by the main field of scientific research, such as city planning, city services, legislation, and technical infrastructure. The structure field denotes core areas of potential research work. It should be noted that some fields are at intersections and can be combined to form major fields of study, for example, business, finance, e-government, and land management. Methods field represents the list of scientific research methods that can be used to study a specific subfield. 
Table 1. Overview of smart city research subfields

\begin{tabular}{|c|c|c|c|}
\hline Subfield & Field(s) of research & Structure & Methods \\
\hline $\begin{array}{l}\text { Transport and roads } \\
\text { system }\end{array}$ & $\begin{array}{l}\text { City planning } \\
\text { Services } \\
\text { Legislation } \\
\text { Technical } \\
\text { infrastructure }\end{array}$ & $\begin{array}{l}\text { International, national, and } \\
\text { local road cover } \\
\text { Airports } \\
\text { Railway system } \\
\text { Water transportation } \\
\text { system }\end{array}$ & $\begin{array}{l}\text { Analysis and } \\
\text { hypothesis } \\
\text { Legal research } \\
\text { Quantitative } \\
\text { System modeling }\end{array}$ \\
\hline Critical infrastructure & $\begin{array}{l}\text { City planning } \\
\text { Services } \\
\text { Legislation } \\
\text { Technical } \\
\text { infrastructure }\end{array}$ & $\begin{array}{l}\text { Waste management } \\
\text { Water management } \\
\text { Gas and gasoline transit } \\
\text { system, management }\end{array}$ & $\begin{array}{l}\text { Legal research } \\
\text { Quantitative } \\
\text { System modeling }\end{array}$ \\
\hline $\begin{array}{l}\text { Land cover and spatial } \\
\text { development }\end{array}$ & $\begin{array}{l}\text { City planning } \\
\text { Technical } \\
\text { infrastructure }\end{array}$ & $\begin{array}{l}\text { Architectural city planning } \\
\text { Construction } \\
\text { Real estate market } \\
\text { Land use }\end{array}$ & $\begin{array}{l}\text { Legal research } \\
\text { Quantitative } \\
\text { System modeling }\end{array}$ \\
\hline $\begin{array}{lr}\text { Population } & \text { dynamics, } \\
\text { activities, } & \text { and } \\
\text { healthcare } & \end{array}$ & $\begin{array}{l}\text { City planning } \\
\text { Services } \\
\text { Legislation }\end{array}$ & $\begin{array}{l}\text { Public healthcare } \\
\text { Policies and regulations } \\
\text { Public transportation } \\
\text { system } \\
\begin{array}{l}\text { Employment and social } \\
\text { cover }\end{array}\end{array}$ & $\begin{array}{l}\text { Legal research } \\
\text { Qualitative } \\
\text { System modeling }\end{array}$ \\
\hline $\begin{array}{l}\text { Business and taxation } \\
\text { policies }\end{array}$ & $\begin{array}{l}\text { Services } \\
\text { Legislation }\end{array}$ & $\begin{array}{l}\text { Law and regulation } \\
\text { Taxation system } \\
\text { local/federal/national } \\
\text { Real estate and land market }\end{array}$ & $\begin{array}{l}\text { Legal research } \\
\text { Qualitative } \\
\text { Quantitative } \\
\text { System modeling }\end{array}$ \\
\hline $\begin{array}{l}\text { Green city and } \\
\text { sustainable } \\
\text { development }\end{array}$ & $\begin{array}{l}\text { City planning } \\
\text { Legislation }\end{array}$ & $\begin{array}{l}\text { Energy management } \\
\text { Natural resources and land } \\
\text { use planning } \\
\text { Sustainable development }\end{array}$ & $\begin{array}{l}\text { Analysis and } \\
\text { hypothesis } \\
\text { Legal research } \\
\text { Qualitative }\end{array}$ \\
\hline $\begin{array}{l}\text { Finances and city } \\
\text { budget }\end{array}$ & $\begin{array}{l}\text { City planning } \\
\text { Legislation }\end{array}$ & Financial planning & $\begin{array}{l}\text { Legal research } \\
\text { Quantitative } \\
\text { System modeling }\end{array}$ \\
\hline E-city government & $\begin{array}{l}\text { City planning } \\
\text { Services } \\
\text { Legislation } \\
\text { Technical } \\
\text { infrastructure }\end{array}$ & $\begin{array}{l}\text { E-city public services } \\
\text { E-city government control } \\
\text { services }\end{array}$ & $\begin{array}{l}\text { Legal research } \\
\text { Qualitative } \\
\text { System modeling }\end{array}$ \\
\hline $\begin{array}{l}\text { Security } \\
\text { surveillance }\end{array}$ & $\begin{array}{l}\text { Services } \\
\text { Legislation } \\
\text { Technical } \\
\text { infrastructure }\end{array}$ & $\begin{array}{l}\text { City surveillance system } \\
\text { City security and response } \\
\text { system }\end{array}$ & $\begin{array}{l}\text { Legal research } \\
\text { Qualitative }\end{array}$ \\
\hline $\begin{array}{l}\text { Power grid and energy } \\
\text { management }\end{array}$ & $\begin{array}{l}\text { Services } \\
\text { Technical } \\
\text { infrastructure }\end{array}$ & $\begin{array}{l}\text { Power management and } \\
\text { distribution } \\
\text { Power system security and } \\
\text { surveillance }\end{array}$ & $\begin{array}{l}\text { Qualitative } \\
\text { Quantitative } \\
\text { System modeling }\end{array}$ \\
\hline $\begin{array}{l}\text { Data management and } \\
\text { prediction systems } \\
\text { Tourism, green areas, } \\
\text { and natural resource } \\
\text { management }\end{array}$ & $\begin{array}{l}\text { City planning } \\
\text { Services } \\
\text { City planning } \\
\text { Services } \\
\text { Legislation }\end{array}$ & $\begin{array}{l}\text { Analytics and prediction } \\
\text { information system } \\
\text { City green areas planning } \\
\text { Tourism planning } \\
\text { Natural resources } \\
\text { management }\end{array}$ & $\begin{array}{l}\text { Quantitative } \\
\text { System modeling } \\
\text { Analysis and } \\
\text { hypothesis } \\
\text { Legal research }\end{array}$ \\
\hline
\end{tabular}


In the context of the presented research work author overviewed plenty of scientific papers and information on urbanization, land management, and computer science areas. The qualitative method was used to establish the smart city study in the context of a broader research field of urbanization. The quantitative method helped us outline the main economics and finance parameters for smart city management system. Another key research output is the importance of using presented tools and methods to make a model of the smart city land management service with an emphasis on map and land surveillance, statistics services. The author employed scientific abstraction, system modeling, and theoretical generalization to build a concept of smart city concept system and establish requirements for the technical implementation of such model. In Table 2 author presents a classification list of the most commonly used research tools in the smart city field. The list includes seven major toolsets together with their classification - digital tools and technologies, technical tools, information systems, computational systems, management systems, analytical and prediction systems. Information that is presented in Table 2 is divided into five sections. There are three important sections that we should note - tool component, tool data types, and field of application. The components section presents empirical sub-areas that can be used for a specific study, while the data field denotes a major data type that is used by this tool, to help form an opinion on which tool to use for specific research work. In the application section, we present the list of research subfields that this tool can be used in.

Table 2. Smart city research tools classification

\begin{tabular}{|c|c|c|c|}
\hline Tool & Components & Data & $\begin{array}{l}\text { Application } \\
\text { subfields }\end{array}$ \\
\hline $\begin{array}{l}\text { Digital tools and } \\
\text { technologies }\end{array}$ & $\begin{array}{l}\text { Servers and computational } \\
\text { resources } \\
\text { Digital mapping and GIS } \\
\text { 3D visualization tools } \\
\text { Telecommunication } \\
\text { technologies }\end{array}$ & $\begin{array}{l}\text { Digital Images } \\
\text { Numerical data } \\
\text { 3D objects data } \\
\text { Land use data } \\
\text { Geographic data } \\
\text { and information }\end{array}$ & $\begin{array}{l}\text { City management } \\
\text { and governance } \\
\text { Architectural } \\
\text { planning }\end{array}$ \\
\hline $\begin{array}{l}\text { Misc. technical tools and } \\
\text { equipment }\end{array}$ & $\begin{array}{l}\text { 3D/LiDAR scanners } \\
\text { Land Surveillance UAVs } \\
\text { Camera surveillance } \\
\text { Sensors and misc. } \\
\text { surveillance systems }\end{array}$ & $\begin{array}{l}\text { Digital images } \\
\text { Numerical data } \\
\text { Sensors data }\end{array}$ & City surveillance \\
\hline Information system & $\begin{array}{l}\text { Data input } \\
\text { Data mining } \\
\text { Data storage } \\
\text { Data presentation }\end{array}$ & $\begin{array}{l}\text { Digital Images } \\
\text { Numerical data } \\
\text { Text and general } \\
\text { information } \\
\text { Visual data }\end{array}$ & E-city government \\
\hline Computational system & $\begin{array}{l}\text { Computational system } \\
\text { Computer Vision and } \\
\text { object recognition }\end{array}$ & Digital data & $\begin{array}{l}\text { Data and system } \\
\text { modeling }\end{array}$ \\
\hline Management system & $\begin{array}{l}\text { Digital documents, } \\
\text { taxation, and e-commerce } \\
\text { City governance and } \\
\text { surveillance } \\
\text { Security and critical } \\
\text { resources management } \\
\text { Communication system }\end{array}$ & $\begin{array}{l}\text { Digital data } \\
\text { Sensors data } \\
\text { Text and general } \\
\text { information }\end{array}$ & $\begin{array}{l}\text { Land use and spatial } \\
\text { planning } \\
\text { E-city government }\end{array}$ \\
\hline Analytical system & $\begin{array}{l}\text { Big Data analytics } \\
\text { Machine learning } \\
\text { City statistics }\end{array}$ & $\begin{array}{l}\text { Numerical data } \\
\text { Digital Images }\end{array}$ & $\begin{array}{l}\text { Real estate } \\
\text { E-city government }\end{array}$ \\
\hline Prediction system & $\begin{array}{l}\text { Machine learning } \\
\text { Data modeling }\end{array}$ & $\begin{array}{l}\text { Digital data } \\
\text { Visual data }\end{array}$ & E-city government \\
\hline
\end{tabular}




\section{Results}

Cities consist of residents, land, and buildings as well as various types of public institutions. People are the main catalyst and through their activities serve as the main drive for cities to change and develop. The city population consists of both residents and nonresidents, such as tourists or business travelers. The city is governed by local authorities, city council or city administration, country or federal government have some level of influence on the city as well. While businesses and international profit and non-profit organizations can take part in city development or affect its growth at any rate. Figure 4 summarizes the list of main actors, roles in the context of a city, and how they interact with the city in general. Services are at forefront of any type of city-related activity, services can either be provided or used. City budget, taxation policies, and legislation affect what are these services and how are they provided by the city authorities. Construction, land use regulation and patterns, environmental exploitation, and ecological situation all directly affect the city and its population.

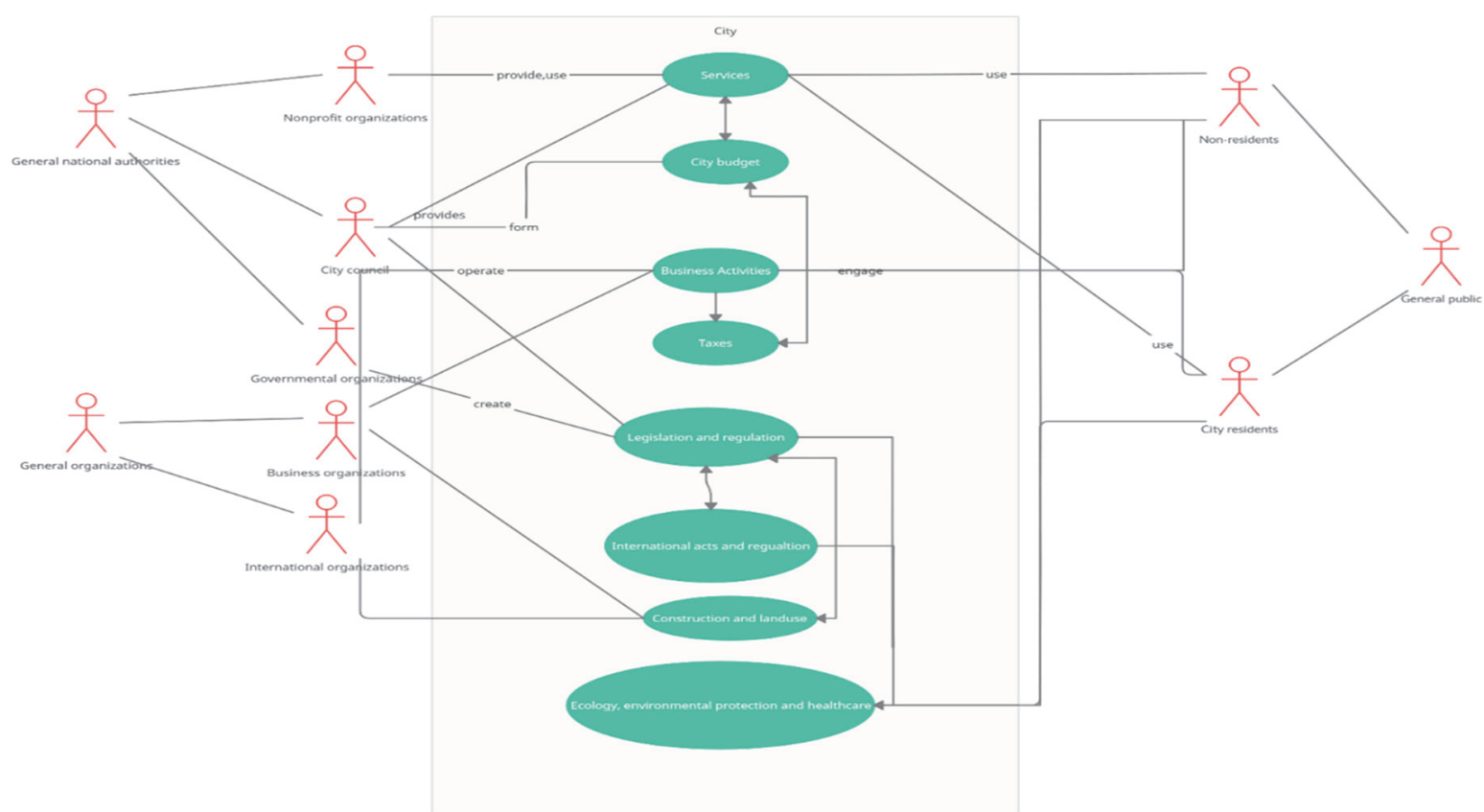

Figure 4. Main roles and major use case scenarios in the context of city activities

Use case scenarios to help us understand the city from a border context, including different viewpoints and major sections of city governance, and functions. All the above-mentioned data is used to create a conceptual model of the smart city. Figure 5 presents a service-centered smart city conceptual model. There are three main categories/groups of people who can operate with such a system, both directly or be indirectly affected by it. Each of the city services can have different service providers, for instance, private organizations or municipal social services, or rely on citizens to carry it out. 


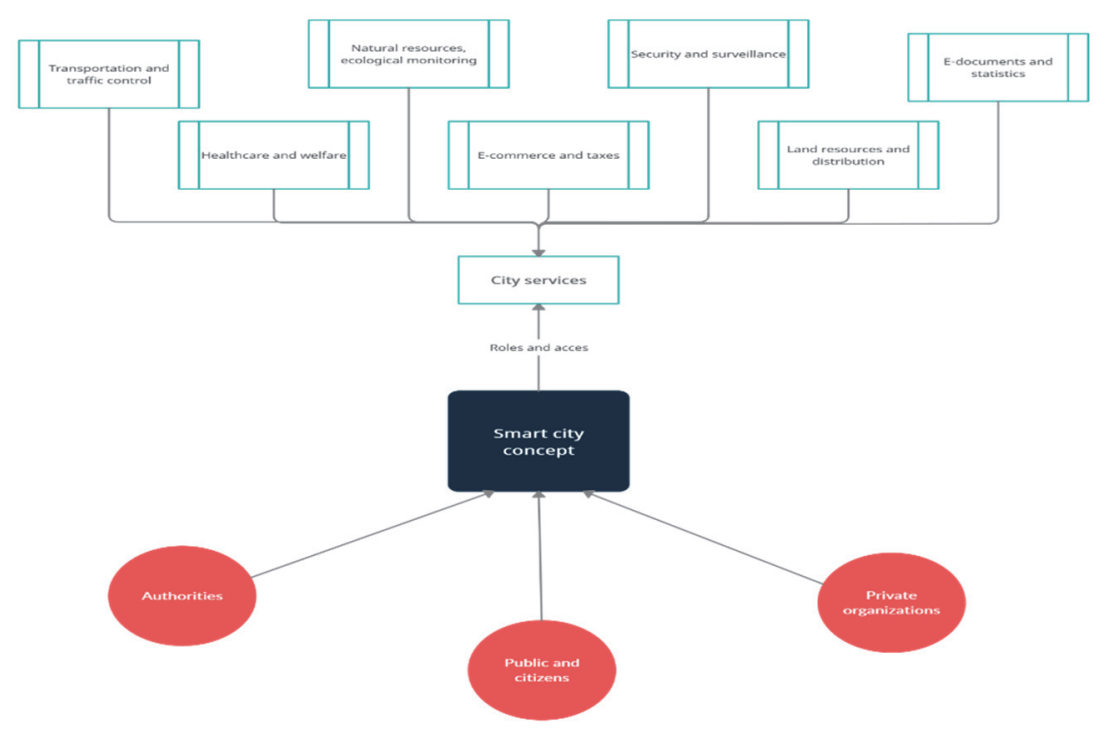

Figure 5. Smart city conceptual model

Computer science tools and methods are widely used in all major fields of scientific research. Smart city information system one of such fields. Table 3 provides a list of major information system analysis tools that can be employed by a scientist working on smart city and land management research fields. Table 3 is an extension of Table 2 and focuses specifically on computer systems set of tools.

Table 3. Smart city information system tools and data by categories

\begin{tabular}{|c|c|c|c|c|}
\hline Category & Tools & Includes & Data types & Part of (cat.) \\
\hline Social & $\begin{array}{l}\text { Information } \\
\text { systems }\end{array}$ & $\begin{array}{l}\text { Employment } \\
\text { Prices and market } \\
\text { Housing market } \\
\text { Public health and } \\
\text { emergency } \\
\text { response }\end{array}$ & $\begin{array}{l}\text { Demographical } \\
\text { Statistical } \\
\text { Charts and graphs } \\
\text { Documentation }\end{array}$ & $\begin{array}{l}\text { Decision support } \\
\text { Information } \\
\text { presentation } \\
\text { Planning }\end{array}$ \\
\hline Economical & Information system & $\begin{array}{l}\text { Investments } \\
\text { Import } \\
\text { Export } \\
\text { Economic policies }\end{array}$ & $\begin{array}{l}\text { Financial } \\
\text { Statistical } \\
\text { Documentation } \\
\text { Charts and graphs }\end{array}$ & $\begin{array}{l}\text { Decision support } \\
\text { System modeling } \\
\text { Information } \\
\text { presentation } \\
\text { Planning }\end{array}$ \\
\hline $\begin{array}{l}\text { Financial } \\
\text { resources }\end{array}$ & Information system & $\begin{array}{l}\text { City budget } \\
\text { Taxation }\end{array}$ & $\begin{array}{l}\text { Financial } \\
\text { Statistical } \\
\text { Charts and graphs }\end{array}$ & $\begin{array}{l}\text { Information } \\
\text { presentation } \\
\text { Planning }\end{array}$ \\
\hline $\begin{array}{l}\text { Production and } \\
\text { industry }\end{array}$ & $\begin{array}{l}\text { Digital document } \\
\text { management }\end{array}$ & $\begin{array}{l}\text { Land use } \\
\text { Location and area } \\
\text { Agricultural } \\
\text { production }\end{array}$ & $\begin{array}{l}\text { Documentation } \\
\text { Map data }\end{array}$ & $\begin{array}{l}\text { Decision support } \\
\text { System modeling } \\
\text { Information } \\
\text { presentation } \\
\text { Planning }\end{array}$ \\
\hline Ecological & $\begin{array}{l}\text { Digital recording } \\
\text { devices } \\
\text { Policies } \\
\text { International } \\
\text { agreements }\end{array}$ & $\begin{array}{l}\text { Waste management } \\
\text { Green areas } \\
\text { Air quality } \\
\text { monitoring }\end{array}$ & $\begin{array}{l}\text { Statistical } \\
\text { Charts and graphs } \\
\text { Map data }\end{array}$ & $\begin{array}{l}\text { Decision support } \\
\text { System modeling } \\
\text { Information } \\
\text { presentation } \\
\text { Planning }\end{array}$ \\
\hline Spatial & GIS & Topology & Map data & Information \\
\hline
\end{tabular}




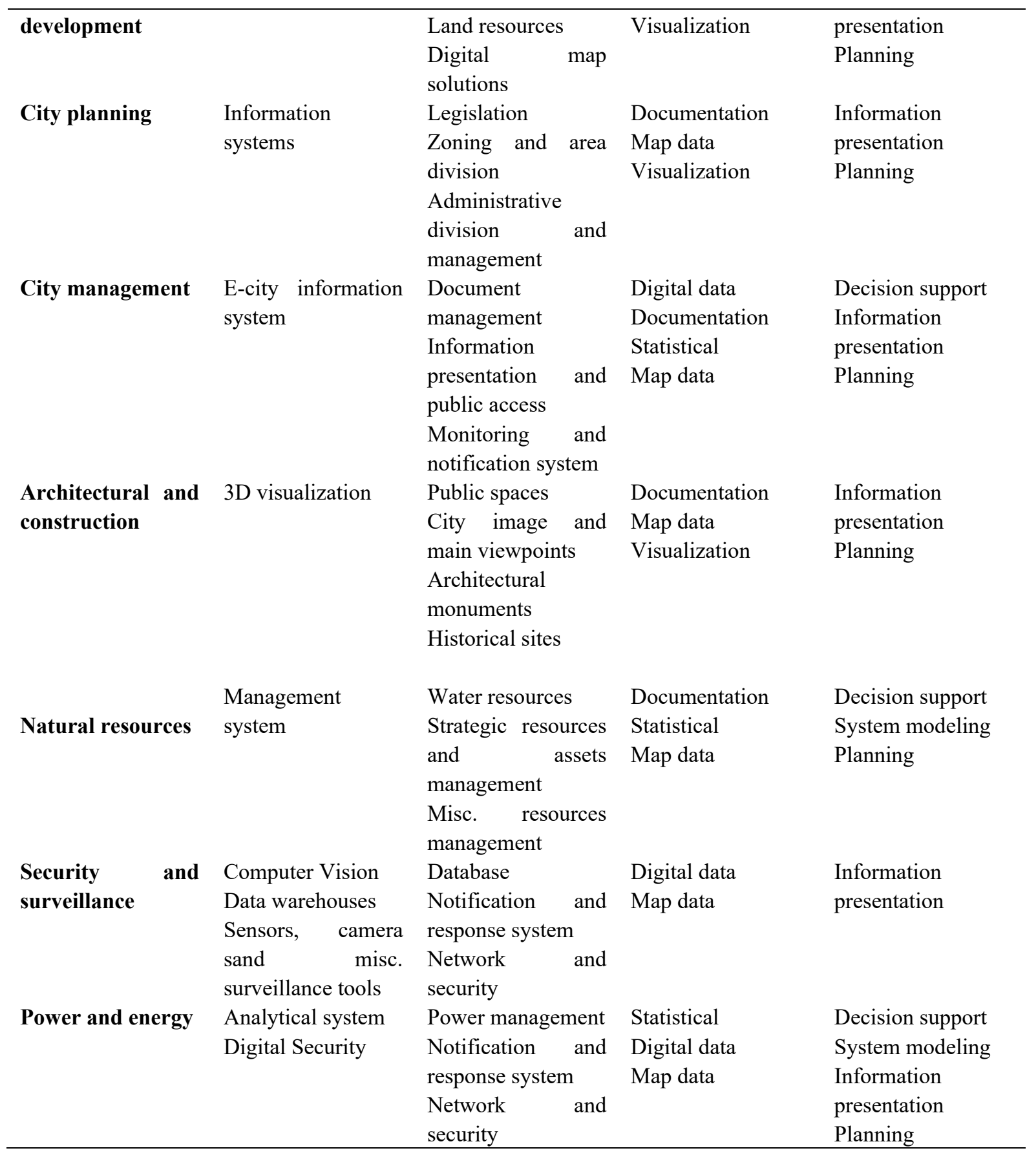

There are many types of data that are used in urbanization research. Three major types of data that are specifically used in the smart city research subfield are - numerical data (financial, distance, statistical, etc.), geographic data and information (incl. maps and digital visualization of cities), text information (city plan, laws, and municipal acts, etc.). Smart City research requires a researcher to work and analyze tremendous amounts of various types of data. We should note that detailed examination, classification, and presentation of all the relative smart city and urban data falls outside of the scope of the present research work and may be published as separate research work in the future. 


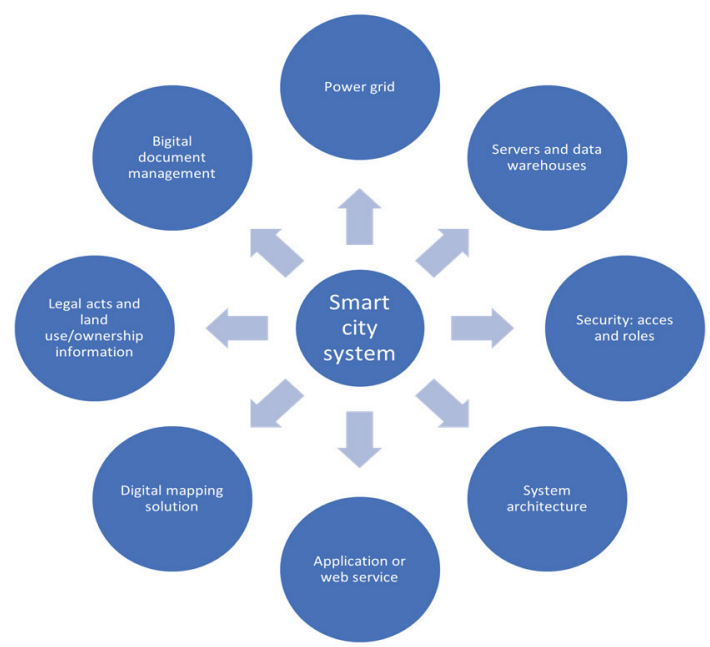

Figure 6. Smart city technical requirements model

Figures 6 and 7 illustrate sample smart city architecture as well as denote main technical requirements. Figure 6 specifically describes essential complements and informational system sections of the smart city conceptual system. Smart city system consists of three sections - city-wide array of sensors and surveillance devices, software solution - interface for people to interact with smart city system and technological infrastructure of the smart city computational cluster.

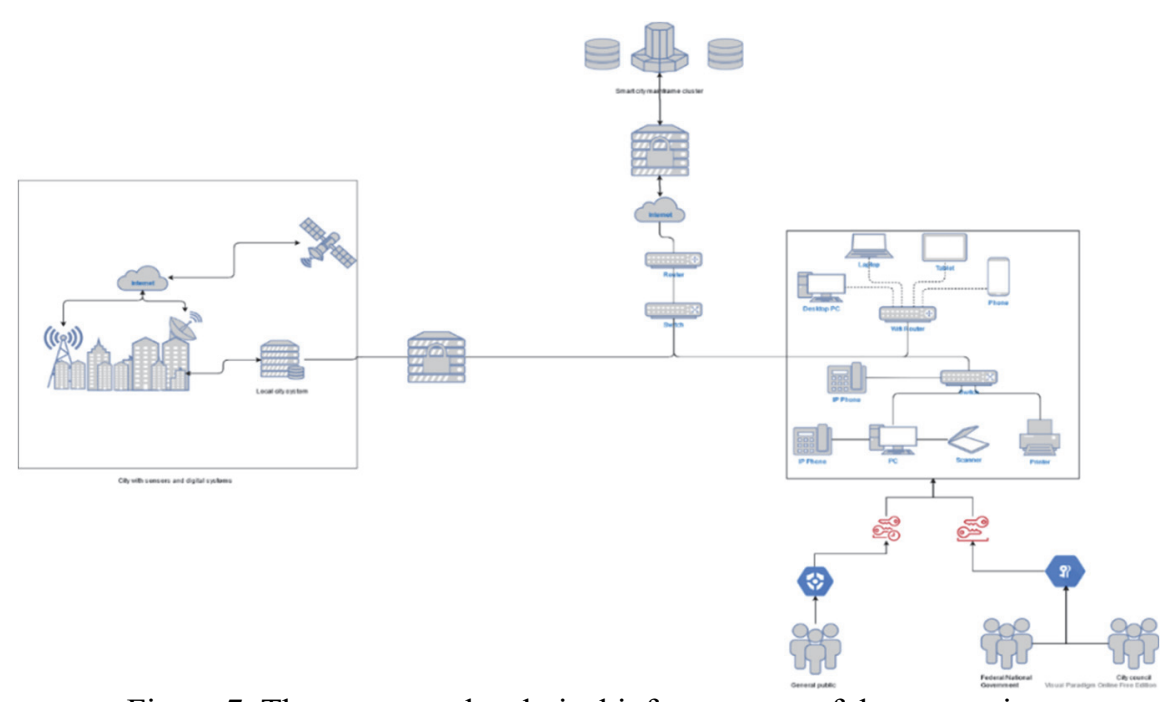

Figure 7. The conceptual technical infrastructure of the smart city

\section{Discussion}

Effective research work starts with first defining the problem, gathering relative data, classifying or categorizing it, and then analyze the data available, to build an effective research model. In the majority of the research process scenarios, the data that is required to conduct research work is multidimensional in nature. Such research data is gathered using various sources, it is usually not directed correlated, such as financial data, digital images, and land use regulations. Nowadays any new researcher has more tools, data, and information at their disposal than those two or three decades ago. Information and computational systems are the basic, essential set of tools for modern urban, land, or city researcher. Such information or computational systems, both require first to choose data type, then input it to be inputted, set the parameters. All these steps are required to be handled before starting the modeling process. Larger quantities of data that are used in smart cities research modeling are either of numerical or geographical type, while some research efforts require both. 
Smart city is a multidimensional, cross-disciplinary field of study, that can be completely explored within the realm of a single research article. For the purpose of empirical research, the outcome author used the land management section of the general smart city service solution. We used toolsets, methods, and information presented in the introductory and main sections of this paper to develop a concept of smart city land management sub-service. The result of this effort is presented in Figure 8. Presented service consists of three main sections, database, information presentation and data visualization layers, computational and processing server. There are five important aspects of smart land management system designs presented in the bottom section of Figure 8. Careful attention should be given to them when making such a system. How software and technical infrastructure will be developed and managed, what is the required way of presenting special data (different research or practical work required a special kind of visual presentation). Spatial and land data is huge in amounts and is already available in different formats, from various sources, coming from open-source solutions, or personal research works, so the proposed system should be able to mine and auto classify this data effectively.

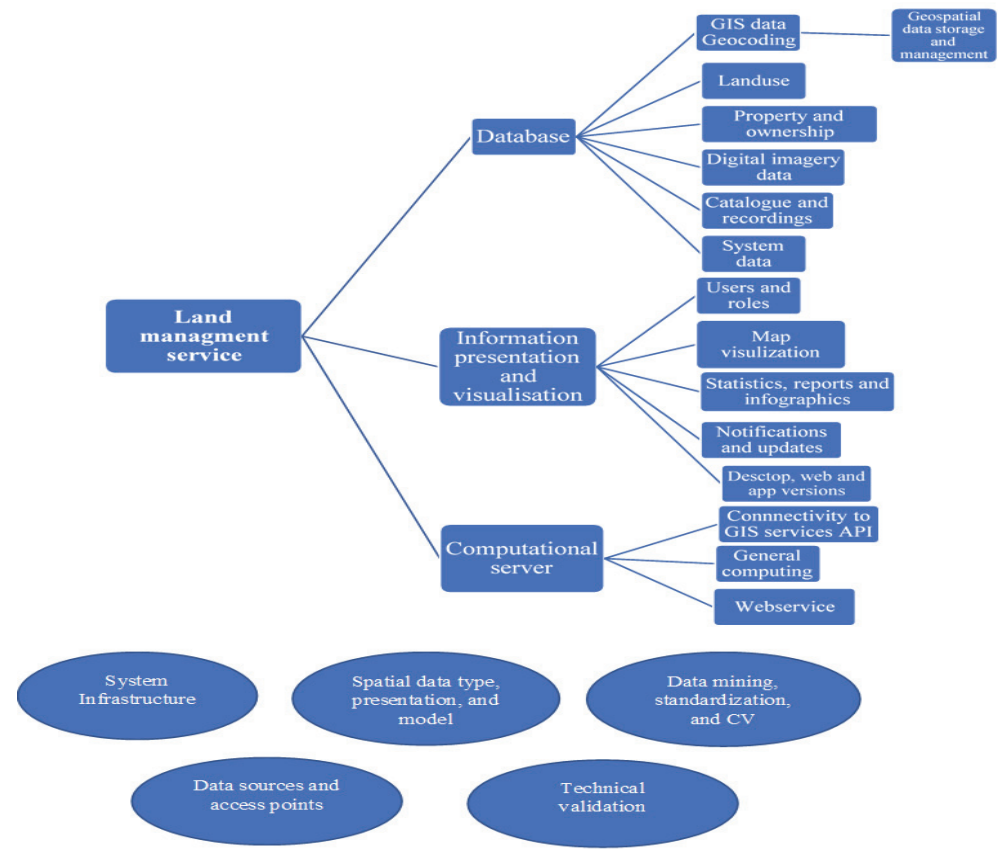

Figure 8. Smart City Land Management service with an emphasis on map and land surveillance, statistics services

In Figure 9 we present information systems that handle land management aspects of smart city systems. Interaction with such a system is conducted in four stages. The first stage is about choosing the right general land data category, for example, water or land resources, power grid or road infrastructure, buildings street cover, or real estate and property. The next step would be to pick the most relative set of tools, this step can be carried in automatic mode when the system chooses the most relevant toolset for the resource category. The toolset also determines what type of output; information presentation will happen at the end of the process. For systems to do their work data is required. This data is manually inputted into the system and then it is classified by its type, or this step can be done in manual mode. At the end of the system operation process, it presents an output, in our case, such a system has five output types, sot of them is related to digital map information presentation. This output includes a set of tools that can be used to better understand the output or conduct necessary post-processing work with the output data. 
We should note that ecology and climate monitoring, together with available water resources visualization are essential parts of any prominent urban research or smart city modeling.

\begin{tabular}{|c|c|c|c|}
\hline Resources categc & Toolset (sub: & Data type (map layer) & System output \\
\hline \begin{tabular}{l|} 
- Water \\
- Land \\
Agricultural, livestock and \\
cropland areas \\
- Forests and green areas \\
- Soil and terrain \\
- Buildings and \\
constructions \\
- Engineering and power \\
systems zones \\
- Transport and road \\
infrastructure cover \\
- Special areas/restricted \\
use zones \\
- Real estate and property \\
- Historical zones and \\
landmarks
\end{tabular} & $\begin{array}{l}\text { - Land use policies } \\
\text { and regulation acts } \\
\text { - Acquisition } \\
\text { - Registration } \\
\text { - Survey } \\
\text { - Finance and tax } \\
\text { - Documentation } \\
\text { - Use monitoring and } \\
\text { control } \\
\text { Use planning } \\
\text { - Allocation } \\
\text { - Ecological } \\
\text { monitoring } \\
\text { - Sustainability and } \\
\text { climate response } \\
\text { - Resources } \\
\text { degradation and } \\
\text { regeneration } \\
\text { - General surveillance }\end{array}$ & $\begin{array}{l}\text { - Topographic } \\
\text { Air quality } \\
\text { : Gater resources } \\
\text { Green cover } \\
\text { Soil } \\
\text { - Streets and buildings } \\
\text { ownerty and } \\
\text { - Powership } \\
\text { engineering and } \\
\text { infrastructure } \\
\text { - Water supply and } \\
\text { waste } \\
\text { - Transport } \\
\text { infrastructure } \\
\text { - 3D visualisation and } \\
\text { simulation } \\
\text { - Misc. hazards } \\
\text { - Special restricted } \\
\text { view/access zone }\end{array}$ & $\begin{array}{l}\text { - General city planning } \\
\text { Objects (buildings } \\
\text { etc.) placement and } \\
\text { construction } \\
\text { - Recultivation and } \\
\text { natural resource } \\
\text { regeneration } \\
\text { - Property, land } \\
\text { ownership and } \\
\text { market } \\
\text { - Ecology and climate } \\
\text { situation monitoring }\end{array}$ \\
\hline
\end{tabular}

Figure 9. Land management, mapping, and GIS system in the context of Smart city

\section{Conclusion}

3D modelling, map visualization, and simulation are among the most useful, modern, and prominent fields of study. These tools help researchers not only to present information but conduct real-time data simulations, as well as build prediction models with complete visualization of potential outcomes. Geographical data and information are used to visualize the city and land cover in a virtual 3D environment. Such models can be both static and dynamic. In the latter case, the researcher has the ability to set parameters and test the models in real-time with visualization of research output information. This set of powerful tools require greater computational resources and skills to be tuned and set up. A lot simpler to manage and operate is a digital mapping solution with prebuild set of tools. The potential development of such a digital mapping solution is planned in the future by the author. The user interface, as well as the main tools of this system, is presented in Figure 10. The main emphasis of the interface usability and features is on real-time analytics, various map layers that can be added/removed and worked on simply and straightforwardly. Land management service can be part of a larger smart city system or serve as a standalone tool. An important aspect of land management web services is collaboration and team project management tools. Work that is being done y one person can be visualized across the team that shares the same project, or they can even collaborate with multiple map layer s in real-time. Design and development of such systems is not a trivial task that requires complex system design.

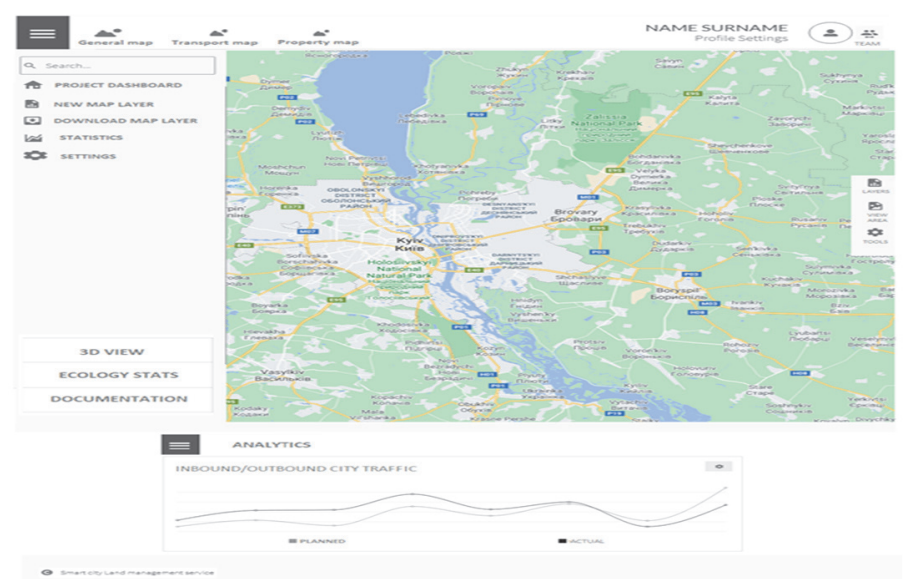

Figure 10. Sample web service user interface for Land Management service 


\section{Acknowledgments}

The author expresses his gratitude towards his family and scientific advisor Dr. Andriy Martyn for their continuous support in this research.

\section{References}

Cisco (2021). Cities and Communities. Retrieved from https://www.cisco.com/c/en/us/solutions/industries/smartconnected-communities.html

Cohen B. (2015). Urbanization, City Growth, and the New United Nations Development Agenda. Cornerstone, $3(2), 4-7$.

Gaur A., Scotney B., Parr G., \& McClean S. (2015). Smart City Architecture and its Applications Based on IoT. Procedia Computer Science, 52, 1089-1094. https://doi.org/10.1016/j.procs.2015.05.122

Glaeser E. L., \& Ward B. A. (2009). The causes and consequences of land use regulation: Evidence from Greater Boston. Journal of urban Economics, 65(3), 265-278. https://doi.org/10.1016/j.jue.2008.06.003

Gries T., \& Grundmann R. (2018). Fertility and modernization: the role of urbanization in developing countries. Journal of International Development, 30(3), 493-506. https://doi.org/10.1002/jid.3104

Harvey J., \& Jowsey E. (2004). Urban land economics. New York, NY: Palgrave Macmillan.

Lo L., Noble E., Levy D., \& Pendall R. (2020). Land Use Reforms for Housing Supply. Retrieved from https://www.urban.org/research/publication/land-use-reforms-housing-supply

Maliene V., Grigonis V., Palevicius V., \& Griffiths S. (2011). Geographic information system: Old principles with new capabilities. Urban Design International, 16(1), 1-6. https://doi.org/16.10.1057/udi.2010.25

McLaren D., \& Agyeman J. (2015). Sharing Cities: A Case for Truly Smart and Sustainable Cities. Cambridge: MIT Press.

National League of Cities (2016). Cities 101 — Budgets. Retrieved from https://www.nlc.org/resource/cities-101budgets

Nazarenko V. (2020). Economic principles and ecological consequences of land use in urban and suburban areas. Land management, cadastre and land monitoring, 2-3, 98-110. http://dx.doi.org/10.31548/zemleustriy2020.02.10

Nazarenko, V. (2018). Current challenges of urbanization - economic view. Land management, cadastre and land monitoring, 2, 97-104. http://dx.doi.org/10.31548/zemleustriy2018.02.097

Online Encyclopaedia Britannica (2021). Information Systems. Retrieved from https://www.britannica.com/topic/information-system/Information-systems-in-the-economy-and-society

Paul J. (2014). Urban Sustainability in Theory and Practice. New York: Routledg.

State Statistics Service of Ukraine (2020). The main indicators of socio-economic development of Ukraine in 2020. Retrieved from http://www.ukrstat.gov.ua

Tatsuhito K., \& Kirti K. J. (2019). Optimal land use regulations in a city with business areas. Traffic Congestion and Land Use Regulations, 104-141. https://doi.org/10.1016/B978-0-12-817020-5.00005-4

United Nations (2018). World Urbanization Prospects. Retrieved from https://population.un.org/wup/Publications/Files/WUP2018-Highlights.pdf

United Nations Department of Economic and Social Affairs Population (2018). Urbanization study. Retrieved from https://www.un.org/en/development/desa/population/theme/urbanization/index.asp.

United Nations Development Programme (2015). Sustainable Development Goals. Retrieved from https://www.undp.org/content/undp/en/home/sustainable-development-goals.html

United Nations Economic Commission for Europe (2008). Spatial Planning: Key Instrument for Development and Effective Governance. Retrieved from https://unece.org/housing-and-land-management/publications/spatialplanning-key-instrument-development-and-effective

United Nations Statistics Division (2004). Land Degradation and Land Use/Cover Data Sources. Retrieved from https://unstats.un.org/unsd/envstats/index.cshtml

Vaquero-García A., Peris-Ortiz M., \& Álvarez-García J. (2017). Urban Models of Sustainable Development from the Economic Perspective: Smart Cities. Sustainable Smart Cities. Innovation, Technology, and 
Knowledge Management, 15-29. https://doi.org/10.1007/978-3-319-40895-8_2

\section{Copyrights}

Copyright for this article is retained by the author(s), with first publication rights granted to the journal.

This is an open-access article distributed under the terms and conditions of the Creative Commons Attribution license (http://creativecommons.org/licenses/by/4.0/). 